\title{
Discussion on the Strategies of Nationalized Chinese Piano Education
}

\author{
Hong Deng and Lin Yu \\ College of Music ,Jiangxi University of Technology
}

Keywords: Nationalization; Piano education; Chinese piano music

\begin{abstract}
With an increasingly higher position of native music education, there are more and more theoretical studies on the nationalization of piano education; however, current studies mainly give reflections on the subject from various perspectives of ideological concept, teaching material system, teaching methods, curriculum standards and so on by calling upon public attention. But there are less studies and imaginations to nationalized teaching material system of Chinese piano education as well as curriculum setting of nationalized Chinese piano education. In this paper, it tries to explore piano education from the perspective of nationalization with emphasis on the study of nationalized contents during piano education. First, it analyzes current situation of Chinese nationalized piano education by doing a survey on Learning Conditions of Chinese Piano Works. The paper can be divided into three parts. The first part is about introduction. In the second part, it analyzes the reasons for deficient nationalized piano education from the perspectives of history, teaching, performance and courses. In the third part, it summarized the investigation with proposal of some personal thoughts.
\end{abstract}

\section{Introduction}

In the $21^{\text {st }}$ century, our society is an information age with economic globalization and strong cultural integration. It has become an urgent need to strengthen ethnic confidence and inspire ethnic spirit by enhancing traditional musical education and carrying forward ethnic musical culture so as to avoid the replacement of cultural integration by economic globalization. Since the sixth National Music Education Seminar in 1995, which was themed as "Music education with Chinese culture as the mother language", there has reached a common sense among musical circle to build a music education system by taking Chinese culture as mother tone. National issues such as "enhancement of traditional music culture education and development of brilliant ethnic culture" and "establishment of musical thoughts by taking Chinese culture as mother language during music education" have become a historic and public need. As far as I am concerned, to conduct music education with Chinese culture as mother language is not merely simple inheritance, but we are carrying forward excellent traditional music culture and arts.

The traditional Chinese culture is extensive and profound; besides, China has given birth to rich and colorful music culture with its 5000-year-long history. Meanwhile, the piano music culture, which integrates Chinese culture with Western culture, has not only embodied unique charm of Chinese piano music, but it also proves the historical achievement that "history can be used to guide today's situation, and western achievements can be applied to Chinese education". Its consolidation, inheritance, promotion as well as development will be realized by educational means and methods. The nationalization of Chinese piano education is based on Chinese ethnic culture and combined with China's basic national condition as well as piano educational practice home and abroad, which aims to form some research results of piano education with Chinese characteristic as well as some 
piano schools with world influence. However, after a hundred years of exploration, piano education in China has still kept western piano teaching system as its piano teaching system, taken western piano teaching mode as its own mode, and copied most teaching contents from western piano teaching contents. Therefore, piano education in China lacks nationalization no matter from perspectives of history and curriculum, or from perspectives of performance and teaching. Although there is a powerful assimilation between eastern culture and western culture, western piano arts and education still play an important role in Chinese piano education, which is far from the expected nationalized system for Chinese piano education.

Therefore, this paper has rightly caught the hot issue of nationalization that has been discussed in recent years. Besides, it combines concrete teaching contents, teaching methods as well as teaching courses of piano education nationalization. On one hand, it discusses the necessity and feasibility of developing nationalized piano education from macro angle; on the other hand, it does a comprehensive survey on Learning condition of Chinese piano works of piano learners from eight schools from micro perspective with the employment of investigation, comparison and analysis so as to find out inefficiency of current Chinese piano education for nationalization. By analyzing the status and reasons, conceptions as well as feasible ideas will be proposed according to ideological concepts, teaching material system and knowledge structure.

Thus, this paper has obvious research values and guiding significance both theoretically and realistically. Study on the nationalization of Chinese piano education can not only correct biased ideas about Chinese piano works, but it can also clarify teaching concepts and point out teaching directions. Moreover, it can help to implement and enforce nationalized piano education as well as teaching of Chinese piano works specifically, which will surely provide certain academic references and guidance for promoting teaching level of Chinese piano works and improving ethnic performance skills of piano learners. The paper tries to make some contributions to the study of ethnic piano education sincerely so as to lay basis for future further study.

\section{The reasons for raising the issue of ethnic Chinese piano education}

Piano has had a four-hundred history in China since it was introduced to Wanli emperor by Matteo Ricci, an Italian preacher in 1601. It still has had an over one-hundred-year history if we take the Opium War as its official beginning. Hundreds of years ago, preachers have established schools to teach music and songs; and then early piano education was established by Shen Xingong, Li Shutong and Xiao Youmei. Afterward, the first school with independent system was established, which was called Shanghai National Music School. Between 1920s and 1930s, piano education had been developed; and then lots of bases were established for piano education between 1950s and 1960s. By far, networks for piano education have been formed with official scales all over the country. In a way, Chinese piano education has earned an important position in Chinese people's musical life. As piano is a product of Western culture, its property and performance is rooted in western musical thoughts, which is suitable for embodying and expressing western musical spirit; so it has lots of disharmony with Chinese musical culture. However, it can be further combined with Chinese ethnic music culture for its convenient transferring, wide range and rich timbres.

Piano education in China has become unprecedentedly active since the reform and opening up. A relatively complete educational system has been formed in each professional musical college.They have formulated standards for artistic and technical teaching in each stage by listing review repertoires for Chinese piano works, which has elevated performance teaching of Chinese piano 
works to an important position. Since the 1980s, Chinese composers have still stuck to Chinese harmony with revolution and experiment; on the other hand, they have made bold explorations on new styles. For example, they have tried to compose piano works with new acoustic structure or pursued ethnic with non-modal and twelve-note system, such as Duo Ye by Chenyi, Wu Kui by Zhoulong, Combination of Long and Short by Quan Jihao, and Dong Xiang Drum Tower by Zou Xiangping, etc. Meanwhile, they have also created unique composing skills with innovative experiment, such as Tai Chi by Zhao Xiaosheng, Landscape Series by Peng Zhimin and The First Sonata for the Piano by Jiang Zupan and so on, all of which have set new landmarks for Chinese piano music.

Chinese piano music is refined from national spirit and it is performed by piano acoustics, so it is undoubtedly national, artistic and international. During the nationalization of Chinese piano music, we found that only if art is combined with ethnic culture that its influence and impact can be brought into play. We should rely on national culture as well as philosophy and aesthetics to make modern art more colorful with extensive culture, high aesthetics and deep philosophy for both its criticism and establishment. With strong and colorful ethnic features, it can be the most real artistic form to express our life deeply and to better embody our national spirit.

\section{Consolidate national music consciousness and carry forward national music spirit}

National spirit is the core and soul of national culture, the spiritual pillar of national survival and development, and the internal impetus of realizing common development and common ideal. In order to guard characteristics of Chinese culture and be independent from world culture, China should possess powerful national spirit. While for the cultivation and promotion of national consciousness and spirit, we need to realize it by ethnic education. That is, individual's national belongings, national values, national belief and understanding of national lifestyle and historical destiny shall be cultivated; and meanwhile particular ideological and behavioral modes as well as ideological feelings of a nation should also be cultivated and promoted.

Chinese piano music is the product of organic combination of advanced scientific and theoretical technology with ethnic music culture, and it is also a historical result of national and ethnic folk music with successful references and rich exploration. Regardless of Chinese piano works adapted from folk instrumental music or folk songs, or creative Chinese works with distinctive characteristic and innovative aggressiveness, they all have to reflect deep ethnic style and strong ethnic spirit. Chinese piano music with Chinese national features and ethnic flavor is just the symbol and presentation of national spirit and national consciousness to some degree. In order to demonstrate special ethnic connotation and spirit of Chinese piano music, we should not only cultivate Chinese piano teachers and learners with common national consciousness and spirit by ethnic education, but most importantly, we should inherit and carry forward such national music consciousness and spirit by nationalized educational means and methods.

\section{Inherit and consolidate Chinese piano music culture}

Chinese piano music culture is the result and witness of excellent history, and it is valuable material and spiritual fortune as well. In order to boom Chinese piano career and make Chinese piano music among top world music with wide reputation, we have no choice but implement ethnic piano education with Chinese characteristic. It is inevitable obligation and responsibility for ethnic 
piano education to consolidate, inherit, promote and carry forward Chinese piano music culture. Kodaly once said that ethnic culture is the symbol of national nature, national dignity and national will, and national music culture is the the most perfect musical performance of national nature since it is a fortune with ethnic significance and national significance as well, which belongs to all human beings. If we want to pursuit musical culture with organism and development in a serious attitude, then we have to make it popular with education.

First, Chinese piano music culture needs to be inherited and consolidated with ethnic piano education.

The traditional Chinese music is extensive and profound. With a five-thousand-year history, China has bred rich and colorful music culture with unique characteristic. Chinese piano music culture is the combination product of Chinese and Western culture, which has not only revealed the unique flavor of Chinese piano music, but also manifested unique charm of Chinese music culture. It is extension and development of traditional music culture to some extent. From perspective of various concrete aspects, it is brilliant achievement by absorbing ancient and foreign essence. From the angle of traditional aesthetics, "neutral beauty" has always been the eternal goal of Chinese music culture. Since the ancient times, Chinese people have been pursuing natural music. We can see that from the following poems. That is, "Music should be joyful but not indecent, mournful but not distressing." Meanwhile, some traditional Chinese music has also embodied the spirit and flavor of Chinese piano music. For example, Three Variations of Plum Blossom and Parting in Yang Guan have shown endless flavor, Autumn Moon on the Calm Lake and The Moon Over a Fountain have indicated a peaceful and poetic situation, Music at Sunset Time and Running Water have manifested peaceful and static environment, all of which are representative works of Chinese piano music.

Second, ethnic piano education is needed to promote and carry forward Chinese piano music.

Although the history of Chinese piano music is no more than one hundred years, it has been widely accepted and employed by Chinese people. Since the creation of piano music with Chinese characteristic by composers like He Lvting in the 1930s, exploration on nationalization for Chinese piano music has begun. According to statistics in the book of Formation and Development of Chinese Piano Culture, between 1925 and 1995, there had been over 600 pieces of Chinese piano works published. However, music is kind of performance art. No matter who created the music work, it should be converted into acoustic sound by performance so as to be recognized and accepted with realization of its real value. Without communicative means and methods, musical works may be existed in the form of music score forever instead of realizing its real value. Several mature western piano schools such as Russian school, German school, French school and Italian school, not only do they have their own composers and piano works, but they are proud of performing their own piano works. In piano competitions, there have always been piano performances with native national characteristic, such as Russian works by Tchaikovsky, German works by Beethoven and Mozart, French works by Debussy and Ravel, Polish works by Chopin, and Hungarian works by Liszt and Bartok. As for Chinese pianists, they should not only possess their own works, but their works should be recognized by the world widely. Chinese piano music should be employed in practice, manifested in performance and witnessed in history. All of this need to be realized by ethnic piano education so as to inherit, promote and carry forward Chinese piano music culture.

In recent decades, with the increasingly deepening promotion of Chinese piano music, lots of piano repertoires have been added to China's piano teaching and large piano competitions to different degrees. As early as in 1991, Chinese piano repertoires have been listed in Chinese Piano 
Teaching Outline by Piano Departments of Central Conservatory and Shanghai Conservatory ( see appendix 3). Departments of Music Education from China Conservatory and Xi'an Conservatory divided piano courses into ten levels, and required piano repertories are listed in each level by demand. At the same time, many normal colleges and universities are also working hard towards this goal with some achievements already. The three piano works of Duo Ye by Chenyi, Combination of Long and Short by Quan Jihao as well as Landscape by Wang Jianzhong have been designated as compulsory repertories as early as in Beijing International Piano Competition hosted by China. In 2000, The Moment of Beijing Opera by Chen Qigang, which is integrated with opera skills and rhythm was also designated as compulsory repertoire. The more attention paid to piano teaching, the more famous Chinese piano music will be around the world. Chinese piano music will be better promoted and developed by constantly exploring excellent Chinese piano works and applying them to teaching actively.

\section{Cultivate ethnic Chinese piano talents and establish Chinese piano school}

The goal of music education is the result that music education needs to realize and the standard that it needs to achieve. The direct goal of music education is to make students feel, express, create and experience music by education so that they can possess basic sense of responsibility and capability to inherit and develop music culture; while the final goal is to cultivate music talents who can adapt to social development with comprehensive qualities. Without support from music talents, music career can't be boomed and developed. Students have a decisive effect on the inheritance and development of music career. So does piano education. In order to give full play to the positive influence of Chinese ethnic piano education, Chinese ethnic piano talents should be relied on. They should be made foundation and powerful strength of Chinese piano career so that they can continue to make contributions to the establishment of Chinese piano school and ethnic piano education.

In a sense, China is not lack of world-class well-known pianist. Internationally, we have Li Yundi, the champion of the 14th International Chopin Piano Competition, and Langlang, a well-known music talent around the world. Domestically, we have lots of excellent piano talents in conservatories. At present, what we need to do is to explore the difference between Chinese and Western piano culture so as to form our own performance features; and meanwhile a Chinese piano music group as well as its representatives should be established to manifest and convey Chinese piano music. Besides widely recognized piano works, the formation of piano school also needs a large group of excellent piano talents who can perform well our own national works. Just as Yang Jun, the famous Chinese piano educationist once said, "we Chinese pianists should not only perform repertoires of Mozart's or Beethoven's well, but we should also do well in our own national works. Then we can call ourselves a real Chinese pianist. If we Chinese can't play Chinese works well, then who can perform well?"

Therefore, we can see development of Chinese piano career relies on talents. Huge efforts are needed for the consolidation of national consciousness, manifestation and communication of piano music, and prosperity and development of piano culture. As a matter of fact, not only a large amount of pianists are wanted, but lots of creators and appreciative experts are required as well in the long run. Moreover, it may even become a national and ethnic task to promote Chinese people's appreciation and entertainment level for piano music. Thus, while paying more attention to ethnic education, we should also lay emphasis on target system, teaching material system, teaching principles, teaching methods of piano education as well as research and formulation of teaching 
contents so as to reflect a systematic national mind. This is an arduous historical task which needs several generations of hard work for a long term. Although there are lots of inefficiencies and defects of Chinese ethnic piano education, it will be developed successfully alongside the ethnic road.

\section{Conclusions}

In the past hundred years, Chinese piano education career has achieved great results since its introduction to China from the establishment of piano educational bases to the prosperous development. While accepting this foreign music culture, we Chinese have also integrate it with ethnic culture by hardworking and cultivation. Now it has grown into a combined product of Chinese and Western culture.

To sum up, while developing Chinese ethnic piano education, we should pay equal attention to the achievements we have achieved as well as kinds of defects and inefficiencies. In terms of teaching materials and teaching methods, we should play more emphasis on the understanding and study of spiritual connotation while adding more Chinese piano works. As for curriculum setting, innovation should be made constantly while learning from other cultures. In terms of teaching circumstance, sound external conditions should be created for Chinese learners.

Certainly, Chinese ethnic piano education is a long-term, complicated and arduous historical process. In this paper, it only presents some immature thoughts based on certain phenomena and issues occurred in the process of ethnic education. Arguments and opinions on Chinese ethnic piano education regarding ethnic consciousness, teaching material system, knowledge structure and curriculum setting may be biased or shallow. I am ready to receive suggestions and instructions from your distinguished teachers and to study together with others.

\section{References}

[1] Bian Meng. Formation and Development of Chinese Piano Culture. Beijing, Huale Press. 1996.

[2] Guan Jianhua. Chinese Music Education and World Music Education at the Turn of the Century. Press of Nanjing Normal University.

[3] Tong Daojin, Sun Mingzhu. Analysis and Performance of Chinese Piano Works. People's Music Publishing House

[4] Zhao Xiaosheng. Methods of Piano Performance. Shanghai Music Publishing House.

[5] Fumin. Fulei’s Letters. Joint Publishing House, 1990.202-203

[6] Fumin. Fulei's Opinion on Music. Hunan Literature and Art Publishing House.

[7] Wang Hongjian. Outline of Arts. Literature and Art Publishing House.

[8] (Spring and Autumn Period) Confucius, translated into English by Willie. The Analects of Confucius, the eighth article. Classics of Masters. Beijing, Foreign Language Press. 1998.

[9] Ji Kanglian. Records of Music. Books about Ancient Music, 1958.

[10]Xiu Hailin, Luo Xiaoping. General Theory of Music and Aesthetics. Shanghai. Press of Shanghai Conservatory of Music, 1994.115 